\title{
Oestrogenic regulation of an egr-1 transgene in rat anterior pituitary
}

\author{
P-S Man and D A Carter \\ School of Biosciences, Cardiff University, PO Box 911, Museum Avenue, Cardiff CF10 3US, UK \\ (Requests for offprints should be addressed to D A Carter; Email: smbdac@cardiff.ac.uk)
}

\begin{abstract}
The $\mathrm{C}_{2} \mathrm{H}_{2}$ zinc-finger transcription factor Egr-1 has previously been shown to play an essential role within the endocrine system as a molecular determinant of LH $\beta$-subunit synthesis in anterior pituitary gonadotrophs. The extent to which Egr-1 may be a dynamic mediator of changes in gonadotroph function during the oestrous cycle is currently unclear. We have recently produced a novel rat transgenic model of egr-1 gene function in which proximal regions of the rat egr-1 gene drive expression of a reporter gene. In the present study, we have investigated the expression and physiological regulation of our egr-1/d4 enhanced green fluorescent protein (EGFP) transgene in the female rat pituitary gland. In situ hybridization analysis has revealed anterior pituitary-specific expression that is limited to a sub-population of cells that includes immunohistochemically defined gonadotrophs. Expression of the transgene is up-regulated 5 -fold following ovariectomy. The transgene also exhibits regulated expression during the oestrous cycle, mRNA levels being significantly raised on pro-oestrus. Using an explant culture system, we have also demonstrated a direct stimulatory effect of $17 \beta$-oestradiol on anterior pituitary transgene and egr-1 expression. The acute response of egr-1 to an oestrogenic stimulus is attenuated by the MEK (MAPK kinase) inhibitor U0126, and is accompanied by increased levels of phospho-p44/42 MAPK protein, suggesting regulation of egr-1 through a MAPK-linked pathway in the pituitary. These findings provide further evidence of cyclical endocrine regulation of egr-1 in the rat, demonstrate that proximal sequences of the egr-1 gene mediate endocrine-regulated expression, and indicate a novel pathway through which pituitary transcriptional responses to oestrogen may be mediated.
\end{abstract}

Journal of Molecular Endocrinology (2003) 30, 187-196

\section{Introduction}

Early growth response gene-1 (egr-1; also termed NGFI-A, zif268, krox-24) is one member of a transcription factor gene family that includes three related genes (egr-2, 3 and 4; see O'Donovan et al. 1999). Extensive analysis of the roles of the DNA-binding protein Egr-1 has revealed important, and unique, roles in fertility (Lee et al. 1996, Topilko et al. 1998), memory (Jones et al. 2001), and the ischaemic stress response (Yan et al. 2000). The first of these roles is of major relevance to endocrinology, because fertility is Egr-1-dependent due to transcriptional regulatory activity of Egr-1 on the pituitary hormone gene that codes for the luteinizing hormone $(\mathrm{LH}) \quad \beta$-subunit (Lee et al. 1996, Topilko et al. 1998; see also Dorn et al. 1999,
Tremblay \& Drouin 1999, Wolfe \& Call 1999, Sevetson et al. 2000, Duan et al. 2002). Recent studies have shown that Egr-1 may also affect fertility through regulation of LH receptor gene expression (Topilko et al. 1998, Yoshino et al. 2002).

The functional association between Egr-1 and the reproductive axis has been explored mainly at the developmental level using null-mutant mice (Lee et al. 1996, Topilko et al. 1998), but our recent studies have provided evidence of an additional association, at a physiological level. Thus, we have described cyclical changes in anterior pituitary Egr-1 activity that correlate with cyclical changes in the reproductive axis in adult female rats (Slade \& Carter 2000). In other studies (Knight et al. 2000), we have shown that the nuclear $75 \mathrm{kDa}$ form of Egr-1 protein is primarily co-localized with LH 
$\beta$-subunit-expressing cells in adult rat anterior pituitary. Taken together, these findings indicate that Egr-1 might play a role in mediating changes in gonadotroph function during the rat oestrous cycle, possibly contributing to the cyclical changes in LH release (Butcher et al. 1974, Fink 1979). This potential role is obscure, however, because gonadotroph function is regulated at multiple levels, and many different molecular factors have now been shown to be associated with this axis (see Brown \& McNeilly 1999). Currently there is no direct evidence to link physiological changes in Egr-1 expression (Slade \& Carter 2000) with changes in gonadotroph gene (LH $\beta$-subunit, or otherwise) expression because the null-mutant genetic models (Lee et al. 1996, Topilko et al. 1998) lack Egr-1 prior to the establishment of reproductive cycles, and adult-onset genetic models have yet to be developed. Consequently, further studies are required to address the physiological role of Egr-1 in the pituitary.

We have recently begun an investigation of $\operatorname{egr}-1$ promoter activity with the aim of developing new in vivo genetic models. Our transgenic model has demonstrated that $1.6 \mathrm{~kb}$ of the rat egr- 1 promoter, together with the egr-1 intron, can direct cellspecific, and regulatable expression in the brain of rats (Slade et al. 2002). In the present study, we have used this model to investigate transgene expression in the anterior pituitary. The use of a promoter-reporter transgenic approach is justified because analysis of transgene expression will inform us of the extent to which the transgene can recapitulate expression of the endogenous egr-1 gene. The consequent insights into the (in vivo) regulatory capacity of the promoter region used in the transgene may, furthermore, have practical applications in the design of secondary transgenic models in which the function of Egr-1 in the pituitary may be addressed through transgenic targeting. Additionally in this study, we have also investigated the physiological factors that determine both transgene and endogenous egr-1 expression in the anterior pituitary.

\section{Materials and methods}

\section{Animal procedures}

All animal procedures were conducted according to UK Home Office regulations, and local ethical review. Sprague-Dawley rats were maintained in approved laboratory conditions on a $14 \mathrm{~h}$ light: $10 \mathrm{~h}$ darkness cycle. Transgenic rats of the $57 \mathrm{C}$ line (Slade et al. 2002) were identified by Southern analysis of BglII-cut genomic DNA using an enhanced green fluorescent protein (EGFP) sequence-specific probe $(1.4 \mathrm{~kb}$ HindIII fragment of pd4 EGFP; Slade et al. 2002). In one experiment, transgenic rats were either ovariectomized using standard surgical procedures and injected with vehicle (s.c. sesame oil, daily on days 8-10 after surgery), ovariectomized and injected with $17 \beta$ oestradiol $\left(\mathrm{E}_{2}\right)$ (Sigma) $(20 \mu \mathrm{g} / 100 \mathrm{~g}$ body weight s.c.) or sham-ovariectomized. Following surgery, rats were maintained for 10 days prior to killing. All other experimental rats were killed on particular days of the oestrous cycle as determined by vaginal cytology (dioestrus day 2 for organ culture experiments; pro-oestrus for in situ hybridization (ISH) analysis). Animals were killed at $1200 \mathrm{~h}$ by decapitation. Anterior pituitary glands were rapidly dissected and rinsed in ice-cold saline before freezing on dry ice prior to subsequent RNA extraction. Alternatively whole pituitary glands were snap-frozen in isopentane cooled with dry ice pellets prior to ISH analysis. Unless otherwise stated, all determinations of gene and protein expression were confirmed with duplicate experimental animals or organ cultures.

\section{Transgene expression analysis}

Total RNA extraction and Northern analysis of transgene and egr-1 transcript expression was performed as described (Slade et al. 2002). Blots were sequentially probed with ${ }^{32} \mathrm{P}$-labelled cDNA probes specific for EGFP (NotI/SalI fragment of pEGFP-N1), egr-1 (EcoRI/DraI fragment of the rat NGFI-A cDNA (Milbrandt 1987)) and 18S ribosomal RNA (DecaTemplate, Ambion, Austin, TX, USA), washed, and exposed to either a Phosphor screen (Kodak-K) (EGFP and egr-1) or X-ray film (18S). Densitometric analysis of mRNA levels between groups was performed using Imagequant software (Amersham Pharmacia Biotech).

ISH histochemical analysis of transgene transcript expression was performed as described (Slade et al. 2002) using antisense and sense ${ }^{35}$ S-labelled RNA probes transcribed using the Riboprobe system (Promega). As reported previously (Slade 
et al. 2002), ISH was used for transgene expression analysis because, despite robust transcription of the transgene, GFP fluorescence deriving from the transgene reporter is not readily detectable. The transgene-specific ISH probe was derived from a plasmid containing 426 bp of pd4 EGFP (bases 971-1396; Clontech, Palo Alto, CA, USA) in pGEM-11Z (Promega). Probe hybridization $\left(1 \times 10^{7}\right.$ c.p.m. $\left./ \mathrm{ml}\right)$ was performed overnight at $56{ }^{\circ} \mathrm{C}$, prior to washing and exposure to a storage phosphor screen (Kodak-K) for 3 days, and subsequent coating in photographic emulsion (LM-1; Amersham Pharmacia Biotech). After 4 weeks, coated slides were developed, counterstained (Mayer's haematoxylin), and viewed with a Leica DM-RD microscope. Images were captured using a Spotcamera (1.30) and Spot Advanced Image software (Spot software 2.2; Diagnostic Instruments, Sterling Heights, MI, USA), imported into Adobe Photoshop $(4 \cdot 0)$.

Dual ISH/immunocytochemistry was performed using a previously described protocol (Allen et al. 1997, Morgan et al. 2000) adapted for gonadotrophs. All solutions used in the initial immunocytochemical step were prepared in diethylpyrocarbonate-treated water, and also contained $0.1 \mathrm{U} / \mu \mathrm{l}$ RNasin ribonuclease inhibitor (Promega). Sections $(8 \mu \mathrm{m})$ of $57 \mathrm{C}$ rat pituitary were post-fixed in 4\% paraformaldehyde in PBS for $5 \mathrm{~min}$, and permeabilized in methanol $\left(-20^{\circ} \mathrm{C}, 2 \mathrm{~min}\right)$. LH $\beta$-subunit immunoreactivity was detected using a Vectastain Elite ABC kit (Vector Laboratories, Burlingame, CA, USA) according to the manufacturer's protocol, using 3,3'-diaminobenzidine as chromogen. The primary antisera to LH $\beta$-subunit (NIDDK-anti-rbetaLHIC-2; AFP22238790 GPOLHB) was diluted 1:1000. Following development of the chromogen, slides were washed, dried and stored at $-70{ }^{\circ} \mathrm{C}$ prior to ISH analysis (see above). Following development of the photographic emulsion, sections were counterstained with Mayer's haematoxylin.

\section{Explant culture of rat anterior pituitary}

Explant culture of rat anterior pituitary fragments was performed as described previously (Carter et al. 1993) with some modifications. The media used was phenol red-free DMEM (Life Technologies) supplemented with penicillin $(100 \mathrm{U} / \mathrm{ml})$ and streptomycin $(100 \mu \mathrm{g} / \mathrm{ml})$. Cultures were maintained at $37^{\circ} \mathrm{C}$ for $24 \mathrm{~h}$ prior to experimental stimuli. Drugs were diluted into the medium to give appropriate final concentrations of $10 \mathrm{nM} \mathrm{E}_{2}$ (Sigma) and $10 \mu \mathrm{M}$ MEK (MAPK kinase) inhibitor U0126 (New England Biolabs, Beverly, MA, USA). Control cultures received similar amounts of drug vehicle (ethanol or DMSO).

\section{Immunoblot analysis}

Western analysis of p44/42, phospho-p44/42 (ERK1/2 (extracellular signal-regulated kinases)), and phospho-p38 MAPK was performed on whole cell anterior pituitary extracts using a protocol described by the manufacturer of the primary antisera (New England Biolabs). Protein concentrations were determined by a dye-binding method (Bradford 1976), and mass estimates were obtained with reference to Broad Range Protein Markers (New England Biolabs). Primary and secondary (anti-rabbit $\mathrm{IgG}$, horseradish peroxidase-linked) antisera used were used at 1:1000 and 1:2000 dilutions respectively. Protein bands were detected by chemiluminescence (Luminol reagent; Santa Gruz Biotechnology, Santa Cruz, CA, USA). The relative level of protein bands were compared using densitometric analysis (Imagequant, see above).

\section{Results}

ISH histochemical analysis demonstrated that the antisense GFP (transgene-specific) probe hybridized to a sub-population (approximately 10-15\%) of anterior pituitary cells (Fig. 1A). The cells exhibiting hybridization were often associated into small groups (Fig. 1A). The aggregations of silver grains that define transgene mRNA expression were restricted to the anterior lobe of the pituitary gland (see Fig. 1C). In control experiments, using a sense GFP probe, there was no evidence of hybridization above background either in the anterior pituitary (Fig. 1B) or in other lobes of the gland (not shown). Immunocytochemical analysis of transgenic rat pituitary glands using a previously characterized (Knight et al. 2000) LH $\beta$-subunit antiserum revealed a sub-population of $\beta$-subunitexpressing cells in the anterior pituitary gland (Fig. 1D). Dual ISH/immunocytochemistry (Allen et al. 1997, Morgan et al. 2000) using the LH $\beta$-subunit 

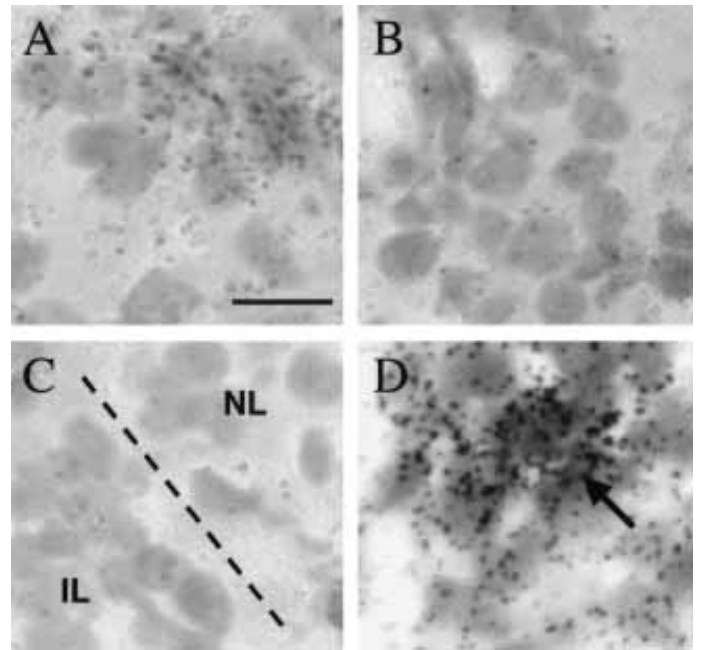

Figure 1 Anterior pituitary-specific expression of egr-1/d4 EGFP transcripts in 57C transgenic rats. ISH histochemical analysis of transgene transcript expression in the pituitary of a female transgenic rat killed on the day of pro-oestrus. Fresh-frozen glands were sectioned $(12 \mu \mathrm{m})$ and probed with a ${ }^{35}$ S-labelled RNA probe specific for transgene (GFP) mRNA.

Emulsion autoradiographs were exposed for 3 weeks.

(A) Representative image of anterior lobe cells probed with antisense GFP probe. Note the presence of a group of cells associated with aggregated silver grains, and other cells associated with a background distribution of silver grains. (B) Representative image of anterior lobe cells probed with sense GFP probe.

(C) Representative image of the neural (NL)intermediate (IL) lobe boundary (dashed line) probed with the antisense probe. (D) Representative image of anterior lobe cells probed with both an LH $\beta$-subunit antisera and the antisense GFP probe. Arrow indicates the association of an aggregation of silver grains with cells exhibiting the orange-brown staining that is representative of LH $\beta$-subunit immunoreactivity. In this grey-scale image, the aggregated silver grains associated with the LH $\beta$-subunit staining are apparent as blacker grains compared with grains not associated with $\mathrm{LH} \beta$-subunit staining. Scale bar $=15 \mu \mathrm{m}$.

antiserum in combination with the antisense GFP probe revealed co-localization of LH $\beta$-subunit immunoreactivity with transgene mRNA (Fig. 1D). The distribution and abundance of silver grain aggregations in the dual analysis sections was similar to that observed for single ISH analysis (Fig. 1A), indicating that the specificity of GFP probe hybridization was not compromised in the dual analysis procedure. Co-localization was observed in the majority of LH $\beta$-subunit-expressing cells; however, a sub-population (approximately 10\%) of
A

Sh Ovx E2

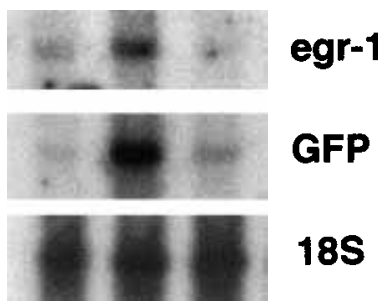

B

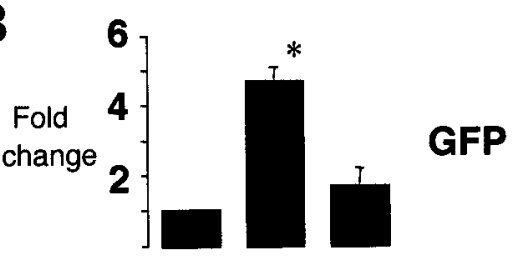

Figure 2 Regulation of egr-1/d4 EGFP transgene, and egr-1 transcript expression in 57C rat anterior pituitary gland following ovariectomy, and oestrogen replacement. (A) Representative Northern blot analysis of transgene, and endogenous egr-1 mRNA in sham-operated (Sh), ovariectomized (Ovx) and ovariectomized, $\mathrm{E}_{2}$-treated (E2) rats. Immobilized total cellular RNA extracted from individual glands $(12 \mu \mathrm{g} /$ lane $)$ was probed sequentially with ${ }^{32} \mathrm{P}$-labelled cDNA probes specific for GFP, egr-1 and $18 \mathrm{~S}$ ribosomal RNA. Blots were exposed to a Phosphor screen (Kodak-K). Exposure times were 3 days (GFP and egr-1) and 10 min (18S). (B) Histogram showing densitometric analysis of multiple GFP Northern blots, as described in $(A)$. Levels of transgene mRNA were corrected against the equivalent level of 18S RNA, and expressed as fold difference over the level for sham-operated animals (means \pm S.E.M.). ${ }^{*} P<0.05$ compared with other groups (ANOVA followed by Duncan's multiple range test). $n=4$ (Sh and Ovx) and 3 (E2) pituitary glands in each group.

$\beta$-subunit-positive/GFP mRNA-negative cells was also observed. Conversely, a similar sub-population of GFP mRNA-positive/ $\beta$-subunit-negative cells was also found, indicating, firstly, that the aggregations of silver grains are not non-specifically associated with immunopositive cells, and secondly, that the transgene is also expressed in a small population of cells other than gonadotrophs.

The capacity of $e g r-1$ genomic sequences within the transgene to mediate transcriptional upregulation in response to physiological (endocrine) stimuli was investigated by observing transgene mRNA levels in ovariectomized rats (Fig. 2), and in rats sampled during the four days of the oestrous cycle (Fig. 3). Following ovariectomy, we found a 
A

D1 D2 $P$ E

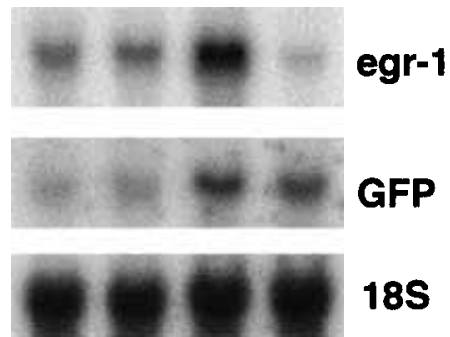

B

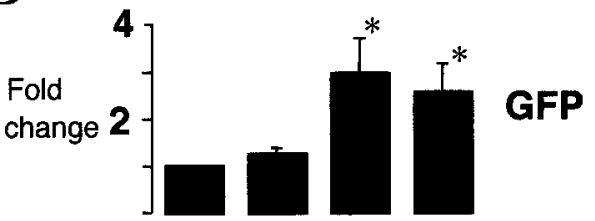

Figure 3 Regulation of egr-1/d4 EGFP transgene transcript expression in $57 \mathrm{C}$ rat anterior pituitary glands during the oestrous cycle. (A) Representative Northern blot analysis of transgene mRNA compared with endogenous egr-1 mRNA. Immobilized total cellular RNA extracted from paired glands (12 $\mu \mathrm{g} / \mathrm{lane})$ was probed sequentially with ${ }^{32} \mathrm{P}$-labelled cDNA probes specific for GFP, egr-1 and 18S ribosomal RNA. Blots were exposed to either a Phosphor screen (Kodak-K; GFP and egr-1) or X-ray film (18S). Exposure times were 2 days (GFP, egr-1) and $1 \mathrm{~h}(18 \mathrm{~S})$. Samples loaded were: D1, dioestrus day 1 ; D2, dioestrus day 2; P, pro-oestrus; E, oestrus. (B) Histogram showing densitometric analysis of multiple GFP Northern blots, as described in (A). Levels of transgene mRNA were corrected against the equivalent level of 18S RNA, and expressed as fold difference over the level for D1 (means \pm S.E.M.). ${ }^{*} P<0.05$ compared with D1 (ANOVA followed by Duncan's multiple range test). $n=3$ samples of paired pituitary glands in each group.

marked and significant $(P<0 \cdot 05)$ elevation of transgene mRNA levels in the anterior pituitary (Fig. 2); this response was reversed by treatment with $\mathrm{E}_{2}$ (Fig. 2). These responses of the transgene were shown to recapitulate regulation of the endogenous egr-1 mRNA (Fig. 2; Slade \& Carter 2000). In intact rats also, we observed regulated expression of transgene mRNA; a significant $(P<0.05)$ up-regulation of transgene mRNA levels was observed on pro-oestrus (Fig. 3), mirroring an endogenous egr-1 mRNA response (Fig. 3). Transgene mRNA levels were generally observed to be reduced on the subsequent day of oestrus, but the reduction was not as great as that observed for endogenous egr-1 transcripts, transgene mRNA levels remaining significantly elevated relative to dioestrous levels (Fig. 3).

In order to investigate the possibility that oestrogen can directly affect transgene (and egr-1) expression in the rat anterior pituitary, a previously characterized (Carter et al. 1993) explant culture model was used. In an initial experiment, the effects of $0,1,10$ and $100 \mathrm{nM} \mathrm{E}$ on $e g r-1$ mRNA levels in wild-type anterior pituitary gland explants were compared. This experiment showed, firstly, that only the 10 and $100 \mathrm{nM}$ concentrations were associated with raised levels of egr-1 mRNA, and secondly that $100 \mathrm{nM}$ did not exert a greater effect than $10 \mathrm{nM}$ (Fig. 4A). Consequently, a $10 \mathrm{nM}$ concentration of $\mathrm{E}_{2}$ was used in further cultures of 57C transgenic pituitary glands. In these studies, $10 \mathrm{nM} \mathrm{E}_{2}$ was shown to effect a significant elevation of both egr-1 (Fig. 4B) and transgene (Fig. 4G) mRNA. However, the time course of these effects differed in that the elevation of egr-1 mRNA was transient, falling significantly at 60 min relative to the $30 \mathrm{~min}$ time point (Fig. $4 \mathrm{~B}$ ), whereas the levels of transgene mRNA remained significantly elevated at $60 \mathrm{~min}$ (Fig. 4G). The rapid, and transient effects of $\mathrm{E}_{2}$ on egr-1 expression are suggestive of signal transduction via the MAPK pathway (see Discussion).

Consequently, an additional series of in vitro experiments were conducted using a specific inhibitor of this pathway, and it was shown that the MEK inhibitor U0126 effected a significant inhibition of the stimulatory effect of $\mathrm{E}_{2}$ on anterior pituitary egr-1 mRNA levels (Fig. 5A and B). In a further study, the effect of oestrogens on anterior pituitary protein kinases was examined, and it was shown that $\mathrm{E}_{2}$ treatment was associated with significantly raised levels of the phospho-p44/42 (ERK1/2) MAPK (Fig. 5C and D), but did not change levels of phospho-p38 MAPK (Fig. 5C).

\section{Discussion}

Previous analysis of our egr- 1 transgenic rat model (Slade et al. 2002) showed that the $e g r-1 / \mathrm{d} 4$ EGFP transgene confers both tissue-specific constitutive expression and inducible expression in the brain. These findings paralleled the results obtained with a recently generated transgenic mouse model (Tsai et al. 2000) in which 5'-flanking sequences of the murine egr-1 gene were shown to direct both 

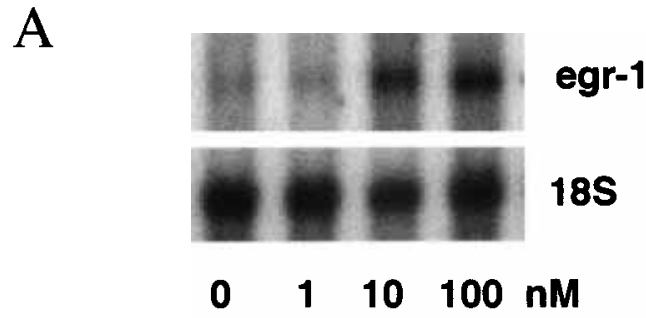

B

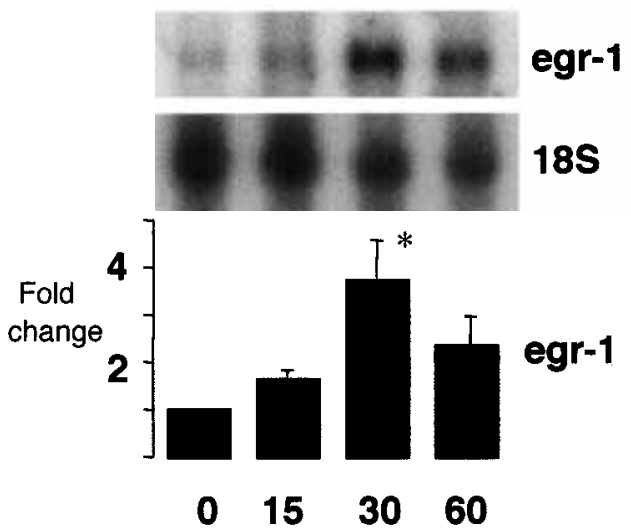

$\mathbf{C}$
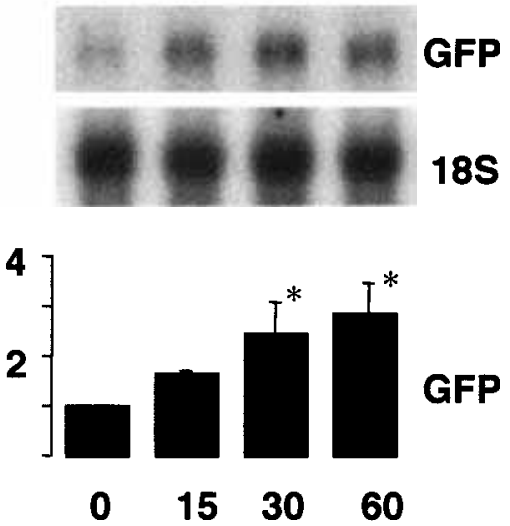

Figure 4 Regulation of egr-1 and egr-1/d4 EGFP transgene expression by oestrogen in explant cultured $57 \mathrm{C}$ rat anterior pituitary gland. (A) Representative Northern blot analysis of egr-1 mRNA in extracts of glands treated with $\mathrm{E}_{2}(0,1,10$ and $100 \mathrm{nM})$ for $30 \mathrm{~min}$. Immobilized total cellular RNA extracted from paired glands $(6 \mu \mathrm{g} / \mathrm{lane})$ was probed sequentially with ${ }^{32} \mathrm{P}$-labelled cDNA probes specific for egr-1 and $18 \mathrm{~S}$ ribosomal RNA. Blots were exposed to either a Phosphor screen (Kodak-K; egr-1) or X-ray film (18S). Exposure times were 3 days (egr-1) and $1 \mathrm{~h}(18 \mathrm{~S})$. (B and C) Representative Northern blot analyses of $(B)$ egr-1 mRNA and (C) transgene mRNA in extracts of glands treated with $E_{2}(10 \mathrm{nM})$ for $0,15,30$ or $60 \mathrm{~min}$. Immobilized total cellular RNA extracted from paired glands ( $6 \mu \mathrm{g} / \mathrm{lane}$ ) was probed sequentially with ${ }^{32}$ P-labelled cDNA probes specific for GFP, egr-1 and 18S ribosomal RNA. Blots were exposed as in (A). Below each Northern blot are corresponding histograms that show densitometric analysis of multiple blots ( $n=3$ individual explant cultures/group). Levels of mRNA were corrected against the equivalent level of 18S RNA, and expressed as fold difference over the level at time 0 (means \pm S.E.M.). ${ }^{*} P<0.05$ compared with time 0 (ANOVA followed by Duncan's multiple range test).

constitutive expression in brain, heart and liver, and hepatectomy-associated gene induction in liver. In the present study, we have now shown that sequences within the rat egr-1/d4 EGFP transgene confer region-specific, and physiologically regulated expression in the rat pituitary gland. Each of these aspects of transgene expression mirror expression of the endogenous egr-1 gene (see Slade \& Carter 2000, Tsai et al. 2000, Slade et al. 2002). Accordingly, the body of data that is emerging from these transgenic studies argues that proximal sequences within the egr-1 gene are sufficient to recapitulate, at least broadly, expression of the endogenous egr-1 gene in rodents. Taken together with extensive in vitro evidence of the regulatory capacity of the $e g r-1$ proximal 5 '-flanking sequence (Changelian et al. 1989, Sakamoto et al. 1991, DeFranco et al. 1993, Gohen et al. 1996, Yan et al. 1999, Bernal-Mizrachi et al. 2000), it can be further argued that this region alone is sufficient 
A
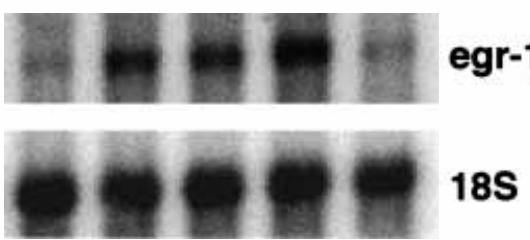

$18 \mathrm{~S}$

\section{E30 E60 V U01}

B

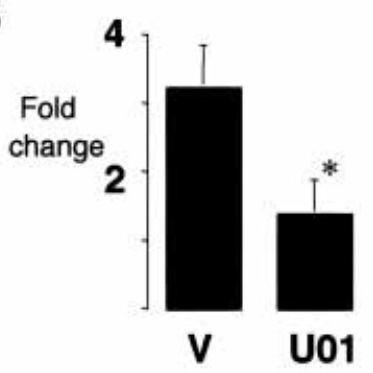

D

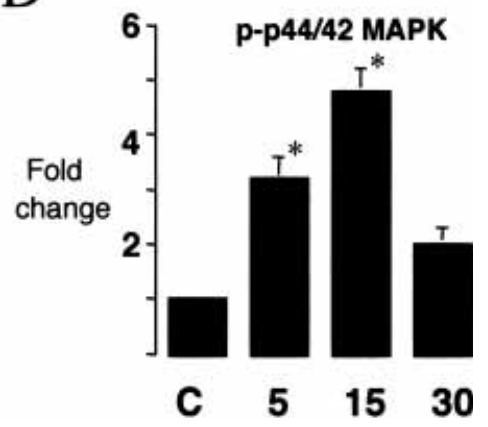

Figure 5 The stimulation of egr-1 expression by oestrogen involves the MAPK pathway. (A) Regulation of egr-1 expression by oestrogen in explant cultured rat anterior pituitary gland. Representative Northern blot analyses of egr-1 mRNA in control glands $(C)$, or glands treated with $E_{2}(10 \mathrm{nM})$ for either 30 or 60 min (E30 and $\mathrm{E} 60)$, or treated with drug vehicle $(\mathrm{V})$ or $\mathrm{U} 0126(10 \mu \mathrm{M}, \mathrm{U} 01)$ for $2 \mathrm{~h}$ prior to treatment with $\mathrm{E}_{2}$. Immobilized total cellular RNA extracted from individual explant cultures $(6 \mu \mathrm{g} / \mathrm{lane})$ was probed sequentially with ${ }^{32} \mathrm{P}$-labelled cDNA probes specific for egr-1 and 18S ribosomal RNA. Blots were exposed to either a Phosphor screen (Kodak-K; GFP and egr-1) or X-ray film (18S). Exposure times were 3 days (egr-1) and $1 \mathrm{~h}(18 \mathrm{~S})$. (B) Histogram showing densitometric analysis of multiple blots as in (A) ( $n=3$ individual explant cultures/group). Levels of mRNA were corrected against the equivalent level of 18S RNA, and expressed as fold difference over the level in control cultures (means \pm S.E.M.). ${ }^{*} P<0.05$ : U0126 vs vehicle (ANOVA followed by Duncan's multiple range test).

(C) Regulation of phospho-p44/42 MAPK by oestrogen in explant cultured rat anterior pituitary gland. Representative Western blot analyses of whole cell protein extracts $(15 \mu \mathrm{g} / \mathrm{lane})$ derived from either control $(\mathrm{C})$ glands, or glands treated with $E_{2}(10 \mathrm{nM})$ for either 5,15 or $30 \mathrm{~min}$. p-p44/42, phospho-p44/42 MAPK; p44/42, p44/42 MAPK; p-p38, phospho-p38 MAPK. (D) Histogram showing densitometric analysis of multiple blots as in (C) $(n=3$ individual explant cultures/group). Levels of phospho-p44/42 MAPK were corrected against the equivalent level of p44/42 MAPK, and expressed as fold difference over the level in control cultures (means \pm S.E.M.). ${ }^{*} P<0.05$ compared with controls (ANOVA followed by Duncan's multiple range test).

to confer an appropriate pattern of expression. However, the presence of consensus, albeit functionally unproven, cis-acting element sequences within the egr-1 intron (incorporated in the rat, but not the mouse transgene) that include a core serum response element (SRE) at base 1444, and an AP-1-like element at base 1682 of the rat egr-1 gene (Acc. No. J04154; Changelian et al. 1989) suggests that a more extensive analysis of the contribution of the $\operatorname{egr}-1$ intron sequences should be conducted. In this context, our transgenic studies of the melatonin-regulating arylalkylamine $\mathcal{N}$-acetyltransferase gene (Burke et al. 1999) have demonstrated an important role of intronic 
sequences for appropriate expression of this gene in the pineal gland.

The demonstrated restriction of Egr-1/d4 EGFP transgene expression to cells of the anterior lobe of the pituitary indicates that the transgene contains sufficient regulatory information to discriminate the embryologically distinct cells of the neural and intermediate pituitary lobes. Within the anterior lobe, transgene transcripts are further restricted to a sub-population of cells indicating that the transgene is also able to mediate cell-type-specific transcriptional control. Thus, using a previously validated (Morgan et al. 2000) dual ISH/ immunohistochemical technique we have demonstrated co-localization of the transgene transcript with LH $\beta$-subunit immunoreactivity. This finding reflects our demonstration of Egr-1 protein in rat gonadotrophs (Knight et al. 2000), and indicates a remarkable fidelity of cell-type-specific expression that is conferred by egr-1 sequences in the transgene. It should be noted that we have also observed cell-type-specific expression of the egr1/d4 EGFP transgene in brain (Slade et al. 2002). The full extent of the cellular specificity of transgene expression in the anterior pituitary will, however, require considerable further analysis in which, firstly, the small population of transgenepositive/LH $\beta$-subunit-negative cell type(s) are characterized, and secondly the co-localization of transgene and $e g r-1$ transcripts is quantified. It is apparent from our results, however, that the former population of cells is limited in number and would not appear to constitute a major anterior pituitary cell type. A similar distribution of expression is observed for Egr-1 protein (see Knight et al. 2000).

Our finding that transgene mRNA levels are up-regulated following ovariectomy, in an oestrogen-dependent manner, is most likely explained by increased hypothalamic drive to the pituitary following the removal of the negative feedback effects of oestrogen. In this respect, LH-releasing hormone (LHRH)-stimulated egr-1 expression has been well documented (Tremblay \& Drouin 1999, Wolfe \& Call 1999, Duan et al. 2002). However, our finding that the egr-1/d4 EGFP transgene is up-regulated prior to the increase in LHRH pulse amplitude that occurs during the night of pro-oestrus (Sarkar et al. 1976) is extremely interesting because our previous studies (Slade \& Carter 2000) have implicated transcriptional regulation of the egr-1 gene by oestrogen, and recently this mode of egr-1 regulation has been directly demonstrated, albeit in other cell types (de Jager et al. 2001). In the present study, using an explant culture model, we have now demonstrated a direct effect of $\mathrm{E}_{2}$ on transgene (and egr-1) expression at the level of the anterior pituitary gland. Therefore, cis-acting sequences within the proximal 5'-flanking, and first intronic region of the rat egr-1 gene appear to mediate an in vivo oestrogenic stimulus. This conclusion may be considered perplexing in view of the absence of consensus oestrogen response elements within this sequence (see Slade \& Carter 2000, de Jager et al. 2001). However, the recent studies of de Jager et al. (2001) have provided evidence that up-regulation of egr-1 by $\mathrm{E}_{2}$ is mediated by SREs within the proximal egr-1 promoter via a mechanism involving the $\mathrm{p} 44 / 42$ MAPK pathway. $\mathrm{E}_{2}$ signalling via the MAPK pathway is, in fact, consistent with an accumulating body of evidence derived from the study of both pituitary cells (Watters et al. 2000) and many other cell types and systems (see Kelly \& Levin 2001). By blocking $\mathrm{E}_{2}$-stimulated egr-1 expression with a specific inhibitor of the MAPK pathway, and demonstrating an increased abundance of phospho-p44/42 MAPK in $\mathrm{E}_{2}$-stimulated pituitary glands, we have now provided further evidence of $\mathrm{E}_{2}$ acting via this pathway. Further studies are now required both to define the cell populations in which MAPK is activated and to establish the functional consequences of the $\mathrm{E}_{2} \rightarrow \mathrm{MAPK} \rightarrow$ g $r-1$ pathway in the pituitary gland.

The in vitro evidence described above has indicated one mechanism through which $\mathrm{E}_{2}$ may influence anterior pituitary gene expression, and consequently effect changes in pituitary cell function during the oestrous cycle. However, the transient up-regulation of pituitary egr-1 mRNA demonstrated here in vitro would not appear to be reflective of a sustained, physiological, egr-1 response to rising levels of $\mathrm{E}_{2}$ over the dioestrouspro-oestrous period, and therefore other factors may modulate the egr-1 response in vivo. It is possible, for example, that $e g r-1$ mRNA half-life may be differentially regulated in vivo (see Cao et al. 1992). In this context, the differences observed between the dynamics of the egr- 1 and transgene mRNA responses are interesting, and most likely reflect the absence of destabilizing $3^{\prime}$ UTR sequences (Wilson \& Treisman 1988) in the transgene transcript. The transient egr-1 response 
may be a phenomenon of the artificially acute $\mathrm{E}_{2}$ stimulation used in the explant culture experiments. Consequently, although the in vitro paradigm has been useful in demonstrating a direct effect of $\mathrm{E}_{2}$ on egr-1/transgene expression at the pituitary level, it may have little further application in probing in vivo mechanisms of egr-1 gene regulation during the oestrous cycle.

In conclusion, we have used a transgenic approach to demonstrate that proximal regions of the egr-1 gene can direct cell-specific and physiologically regulated expression in the anterior pituitary gland. Expression of the transgene, both anatomical and regulated, recapitulates expression of the endogenous egr-1 gene, a finding that reflects observations in an egr-1 transgenic mouse model (Tsai et al. 2000). Therefore, although we have used only a single transgenic line $(57 \mathrm{C})$ for these studies, it is considered unlikely that the observed expression patterns in the pituitary gland are artefactual. Accordingly, our transgene construct could be useful in future studies that are designed to direct expression of functional cDNAs to a subset of pituitary cells. Our novel evidence of a direct effect of oestrogen on transgene (and egr-1) expression at the level of the pituitary, together with previous evidence of $e g r-1$ gene regulation by LHRH, suggests that the molecular response to these two physiological factors may be integrated, possibly through a co-operative action, at the egr-1 promoter.

\section{Acknowledgements}

We declare that there are no conflicts of interest that would prejudice the impartiality of this paper.

\section{References}

Allen DL, Mitchner NA, Uveges TE, Nephew KP, Khan S \& Ben-Jonathan N 1997 Cell-specific induction of c-fos expression in the pituitary gland by estrogen. Endocrinology 138 2128-2135.

Bernal-Mizrachi E, Wice B, Inoue H \& Permutt MA 2000 Activation of serum response factor in the depolarization induction of Egr-1 transcription in pancreatic islet beta-cells. Fournal of Biological Chemistry 275 25681-25689.

Bradford M 1976 A rapid and sensitive method for the quantitation of microgram quantities of protein utilizing the principle of protein-dye binding. Biochemistry 72 248-252.

Brown P \& McNeilly AS 1999 Transcriptional regulation of pituitary gonadotrophin subunit genes. Reviews of Reproduction 4 117-124.

Burke Z, Well ST, Carter D, Klein D \& Baker R 1999 Genetic targeting: the serotonin $\mathrm{N}$-acetyltransferase promoter imparts circadian expression selectively in the pineal gland and retina of transgenic rats. Fournal of Neurochemistry 73 1343-13491.

Butcher RL, Collins WE \& Fugo NW 1974 Plasma concentrations of $\mathrm{LH}, \mathrm{FSH}$, prolactin, progesterone and estradiol-17 $\beta$ throughout the 4-day estrous cycle of the rat. Endocrinology 94 1704-1707.

Cao X, Mahendran R, Guy GR \& Tan YH 1992 Protein phosphatase inhibitors induce the sustained expression of the Egr-1 gene and the hyperphosphorylation of its gene product. Fournal of Biological Chemistry 267 12991-12997.

Carter DA, Chew LJ \& Murphy D 1993 In vitro regulation of rat prolactin mRNA poly (A) tail length: modulation by bromocriptine. Foumal of Neuroendocrinology 5 201-204.

Changelian PS, Feng, P, King TC \& Milbrandt J 1989 Structure of the NGFI-A gene and detection of upstream sequences responsible for its transcriptional induction by nerve growth factor. PNAS 86 377-381.

Cohen DM, Gullans SR \& Chin WW 1996 Urea inducibility of egr-1 in murine inner medullary collecting duct cells is mediated by the serum response element and adjacent Ets motifs. Fournal of Biological Chemistry 271 12903-12908.

DeFranco C, Damon DH, Endoh M \& Wagner JA 1993 Nerve growth factor induces transcription of NGFIA through complex regulatory elements that are also sensitive to serum and phorbol 12-myristate 13-acetate. Molecular Endocrinology 7 365-379.

de Jager T, Pelzer T, Muller-Botz S, Imam A, Muck J \& Neyses L 2001 Mechanisms of estrogen receptor action in the myocardium. Rapid gene activation via the ERK1/2 pathway and serum response elements. Fournal of Biological Chemistry 276 27873-27880.

Dorn C, Ou Q, Svaren J, Crawford PA \& Sadovsky Y 1999 Activation of luteinizing hormone beta gene by gonadotrophinreleasing hormone requires the synergy of early growth response-1 and steroidogenic factor-1. Journal of Biological Chemistry $\mathbf{2 7 4}$ 13870-13876.

Duan WR, Ito M, Park Y, Maizels ET, Hunzicker-Dunn M \& Jameson JL 2002 GnRH regulates early growth response protein 1 transcription through multiple promoter elements. Molecular Endocrinology 16 221-233.

Fink G 1979 Neuroendocrine control of gonadotrophin secretion. British Medical Bulletin 35 155-160.

Jones MW, Errington ML, French PJ, Fine A, Bliss TV, Garel S, Charnay P, Bozon B, Laroche S \& Davis S 2001 A requirement for the immediate early gene Zif268 in the expression of late LTP and long-term memories. Nature Neuroscience 4 289-296.

Kelly MJ \& Levin ER 2001 Rapid actions of plasma membrane estrogen receptors. Trends in Endocrinology and Metabolism 12 152-156.

Knight C, Slade JP \& Carter D 2000 The nuclear, $75 \mathrm{kDa}$ form of Egr-1/NGFI-A is primarily restricted to LH $\beta$-subunit expressing cells in rat anterior pituitary. European Fournal of Endocrinology 143 817-821.

Lee SL, Sadovsky Y, Swirnoff AH, Polish JA, Goda P, Gavrilina GM \& Milbrandt J 1996 Luteinizing hormone deficiency and female infertility in mice lacking the transcription factor NGFI-A (Egr-1). Science 273 1219-1221.

Millbrandt J 1987 A nerve growth factor-induced gene encodes a possible transcriptional regulatory factor. Science 238 797-799.

Morgan H, Smith M, Burke Z \& Carter DA 2000 The transactivation-competent $\mathrm{C}$-terminal domain of AF-9 is expressed within a sexually dimorphic transcript in rat pituitary. FASEB fournal 14 1109-1116.

O'Donovan KJ, Tourtellotte WG, Millbrandt J \& Baraban JM 1999 The EGR family of transcription-regulatory factors: progress at the interface of molecular and systems neuroscience. Trends in Neuroscience 22 167-173.

Sakamoto KM, Bardeleben C, Yates KE, Raines MA, Golde DW \& Gasson JC $19915^{\prime}$ upstream sequence and genomic structure of 
the human primary response gene, EGR-1/TIS8. Oncogene 6 867-871.

Sarkar DK, Chiappa SA, Fink G \& Sherwood NM 1976 Gonadotrophin-releasing hormone surge in pro-oestrous rats. Nature 264 461-463.

Sevetson BR, Svaren J \& Milbrandt J 2000 A novel activation function for NAB proteins in EGR-dependent transcription of the luteinizing hormone beta gene. Fournal of Biological Chemistry 275 9749-9757.

Slade JP \& Carter DA 2000 Cyclical expression of Egr-1/NGFI-A in the rat anterior pituitary - a molecular signal for ovulation? Fournal of Neuroendocrinology 12 671-676.

Slade JP, Man PS, Wells T \& Carter DA 2002 Stimulus-specific induction of an egr-1 transgene in rat brain. Neuroreport $\mathbf{1 3}$ 671-674.

Topilko P, Schneider-Maunoury S, Giovanni L, Trembleau A, Gourdji D, Driancourt MA, Rao GV \& Charnay P 1998 Multiple pituitary and ovarian defects in Krox-24 (NGFI-A, Egr-1)-targeted mice. Molecular Endocrinology 12 107-122.

Tremblay JJ \& Drouin J 1999 Egr-1 is a downstream effector of Gn-RH and synergizes by direct interaction with Ptxl and SF-1 to enhance luteinizing hormone $\beta$ gene transcription. Molecular and Cellular Biology 19 2567-2576.

Tsai JC, Liu L, Cooley BC, DiChiara, MR, Topper JN \& Aird WC 2000 The Egr-1 promoter contains information for constitutive and inducible expression in transgenic mice. FASEB fournal 14 $1870-1872$.
Watters JJ, Chun TY, Kim YN, Bertics PJ \& Gorski J 2000 Estrogen modulation of prolactin gene expression requires an intact mitogen-activated protein kinase signal transduction pathway in cultured rat pituitary cells. Molecular Endocrinology 14 1872-1881.

Wilson T \& Treisman R 1988 Removal of poly(A) and consequent degradation of c-fos mRNA facilitated by $3^{\prime}$ AU-rich sequences. Nature 336 396-399.

Wolfe MW \& Call GB 1999 Early growth response protein 1 binds to the luteinizing hormone- $\beta$ promoter and mediates gonadotropin-releasing hormone-stimulated gene expression. Molecular Endocrinology 13 752-763.

Yan SF, Lu J, Zou YS, Soh-Won J, Cohen DM, Buttrick PM, Cooper DR, Steinberg SF, Mackman N, Pinsky DJ et al. 1999 Hypoxia-associated induction of early growth response-1 gene expression. Fournal of Biological Chemistry 274 15030-15040.

Yan SF, Fujita T, Lu J, Okada K, Shan Zou Y, Mackman N, Pinsky DJ \& Stern DM 2000 Egr-1, a master switch coordinating upregulation of divergent gene families underlying ischemic stress. Nature Medicine 6 13555-13561.

Yoshino M, Mizutani T, Yamada K, Tsuchiya M, Minegishi T, Yazawa T, Kawata H, Sekiguchi T, Kajitani T \& Miyamoto K 2002 Early growth response gene-1 regulates the expression of the rat luteinizing hormone receptor gene. Biology of Reproduction $\mathbf{6 6}$ $1813-1819$

Received in final form 14 October 2002 Accepted 18 November 2002 